\title{
EFL Students' Speaking Activities: The Significance of Games in Classroom Context
}

\author{
Moh. Rofid Fikroni \\ Institut Agama Islam Negeri Jember \\ rofidfiks@gmail.com
}

\begin{abstract}
The learning process of language teaching seems to be very demanding and complicated, especially for speaking skill. Speaking, alongside with writing, is considered to be productive skill in which it requires students to produce the language in spoken form. The students need to be able to speak the language by considering some aspects of speaking such as fluency and accuracy. In other words, not only the student has to speak correctly, but also it has to be as smooth as possible. Such particular case becomes one of the reasons why it is difficult to master the skill itself. in another case, it has become much more difficult for the students to grasp the speaking material. Moreover, designing a speaking environment for language teaching in classroom context is no difference. Due to the fact that the scope of speaking skill is complex, the students are reluctant to say something or use the language. That is why the English teacher needs to come up with specific plans to teach English as second or foreign language. One of ways to overcome the problem is by implementing game. The nature of game will help the English teacher to develop such amusing and enjoyable atmosphere in the teaching and learning process.
\end{abstract}

Keywords: Speaking skill, Teaching Speaking, Media in Teaching Speaking, Games. 


\section{INTRODUCTION}

In the globalization age today, English assumes as a more and more important part as a means of international communication. English takes up a very important position in almost any sectors of use such as business, commerce, academic field, technology, diplomatic circle, etc. Therefore in the academic field or educational purposes, in some recent years, the focus of teaching has been promoting oral skills in order to respond the students' needs for effective communication.

However, due to some objective and subjective reasons, teaching and learning English in general and teaching and learning speaking in particular does not come up to the study aims. Despite teachers' efforts to provide students with opportunities to develop their communicative skills, how to teach and learn speaking effectively is still a challenging question to both teachers and students at many schools.

When the teachers are struggling in designing activities which can develop the students' ability in mastering English, especially in speaking aspect, the students face even a bigger problem. The fact has shown that the students are quite difficult to improve their speaking ability because they are accustomed to use their native language in their daily life than using English. This is the reason why we can not deny the fact that the students still considered speaking skill as the most difficult skill to be mastered. In classroom context, the English teacher often find the students can hardly use English for communicative objectives even in the simplest form.

Meanwhile, the main focus in learning language as second or foreign language had changed. In ancient time, the purpose of mastering the language is to be able to read the literature of the language. In some recent years, the mastery of speaking skills in English is a priority for many second-language or foreign-language learners. Consequently, learners often evaluate their success in language learning as well as the effectiveness of their English course on the basis of how much they feel they have improved in their spoken language proficiency (Jack C. Richards: 2008).

Based on Nguyen and Nguyen (2001), speaking is meant under two aspects: accuracy and fluency. "Accuracy involves the correct use of vocabulary, grammar and pronunciation". "Whereas fluency can be thought of as the ability to keep going when 
speaking spontaneously". When speaking fluently, language learners should be able to get message across whatever resources and abilities what they've got, regardless of grammatical and other mistakes. Meanwhile, many educators believe that in a communicative class "it is not necessary to teach conversational features or push students to communicate accurately" and that "fluency can be developed by simply providing students with lots of conversational practice". Therefore, the requirements of language fluency and accuracy may differ variably due to each stage of language learning.

Nguyen and Nguyen (2001) also introduces some favorablyused strategies in speaking. They are:

1. The use of natural-sounding "incomplete" sentences.

2. The use of common expressions like "Never mind" "You're welcome"...

3. The use of "fillers" and hesitation devices: Well, let me think...

4. The use of communication strategies such as asking for clarifications: "Pardon?" "I don't understand. What do you mean?"...

5. The ability to paraphrase-"put it another way" or explain /describe what they want to say if they haven't got the right language.

Bygate (1987) suggested a more comprehensive discussion of the nature of speaking. It is shown that in order to be able to speak a foreign language, it is obviously necessary to have microlinguistics skills, that is, to understand some grammar, vocabulary and the rules governing how words are put together to form sentences. Bygate (1987) also discusses further at great length the two sub-skills of interaction skills that the speakers use when they speak: the routine skills and negotiation skills. Routines are the conventional ways of presenting information such as descriptions, comparisons, story telling. They can be either expository, concerning presenting factual information, or evaluative where the speakers explain, reason, justify, predict and draw conclusions. They can also be interaction routines that can be found in interactions in different specific situations like interviews or discussions, etc.

According to Windows (1978: 38) in Abidin (2008: 2006) says, speaking a productive rather than receptive and operates 
through the aural rather than the visual medium. Windows adds that speaking for the manifestation or language as usage and refers to the realization of language as use spoken interaction as talking. Speaking knows teacher and student have tied reading translation and analysis as way to enter language, there are partial experience the student does not knows sentence until they speak it. When students red aloud they have manipulated only part of language, according to Jackson Hanna in Maula (1996: 59).

Murcia in Abidin (2001: 103) also says that speaking in activity requiring the integration sub system. There entire factors combine to make speaking second or foreign language learners. Yet many people, speaking are seen as central skills. On the other word, speaking is integrated from pronunciation, complex structure and vocabulary.

From the definitions stated above, it can be concluded that speaking skill refers to oral production in spoken form. There many aspects which need to be taken consideration such as; the use of vocabulary, accuracy, fluently, pronunciation, etc. Therefore, in improving our speaking skill, it is important for us to keep using English as our daily language.

By considering the fact stated above, in this paper the writer would like to discuss this problem further and try to provide the readers the answer of this complicating problem which is by using games. The reason why the writer purposes language games because games can be a very useful teaching technique for the effective and joyful learning. Games also believed can give the positive effect on the students' interest and motivation in studying English as well as to increase their speaking ability.

\section{METHODS}

As this study aims to give comprehensive explanation about the significance of implementing games for language teaching, especially for speaking class, it used qualitative research approach in the form of library research focusing on gathering the information related to the subject studied. The data were collected by using documentation. Moreover, there are two kinds of data used; primary and secondary data taken from any materials such as books, articles, journal articles, and so on which is relevant to the subject described as the supporting data as well as argument provided by the writer. Furthermore, the data was analyzed 
descriptively by using deductive and inductive approach. In addition, content analysis method was also used in analyzing the data as well as drawing conclusion based on the content of the data itself. Likewise, the triangulation process used to validate the data collected. In this particular case, the data was triangulated and compared each other within the authors' perspective related to the significance of games in speaking class context.

\section{RESULTS AND DISCUSSION}

\section{Teaching Speaking Skill by Using Games}

Language is an art. That is why teaching language sometime considered as an art work, it has to be learnt in both theory and practice. Because of this reason, most of teachers are struggling in teaching language as second or foreign language. Especially, when they teach aspect of language which is required the students to produce something such as speaking and writing.

Not only the teacher who face some difficulties here, but the students themselves are in the same situation. According to Gunter, ester and Schwab (2005:7) there are two major problems why the students are difficult to learn English:

1. Whatever the student learns from experience of memorizing word is mostly lost within a few hours or day of the test.

2. The student learns practically nothing about the system of English spelling and word meaning and spelling are connected.

Furthermore, Ur (1996) says that there still exist some problems with speaking activities as follows:

1. Inhibition: Unlike reading, writing and listening activities, speaking requires some degree of real-time exposure to an audience. Learners are often inhibited about trying to say things in a foreign language in the classroom: worried about making mistakes, fearful of criticism or losing face, or simply shy of the attention that their speech attracts.

2. Nothing to say: Even if they are not inhibited, you often hear learners complain that they cannot think of anything to say: they have no motive to express themselves beyond the guilty feeling that they should be speaking.

3. Low or uneven participation: Only one participant can talk at a time if he or she is to be heard, and in a large group this means that each one will have only very little time talking. 
This problem is compounded by the tendency of some learners to dominate, while others speak very little or not at all.

4. Mother-tongue use: In classes where all, or a number of, the learners share the same mother tongue, they may tend to use it: because it is easier, because it feels unnatural to speak to one another in a foreign language, and because they feel less "exposed" if they are speaking their mother tongue. If they are talking in small groups it can be quite difficult to get some classes-particularly the less disciplined or motivated ones- to keep to the target language.

Considering those problems, it is urgently necessary to use devices or tools in teaching language, especially teaching speaking skill. Devices here refer to all of the objects or techniques which can be applied in teaching speaking skill. One of them is by using games. However, why should we use games?

Game is an organize activity which consist of set of rules and have capability to make the students fun and creative, game also can provide an enjoyable atmosphere and interesting way to help the students to acquire the language that is used to communicate. It can be said that game not only function as time filling activities but also they can bring some educational values that enable the children to learn the language.

Usually, games applied in teaching language process, especially in teaching speaking, called language games. Mc Cabe (1992) defines a language games as a spoken routine for two or more players, meant to be repeated many times. This implies that such repetition will enable the children to communicate effectively since playing language games will help the children to develop language and thought. In the activities of language games, the children will develop their ability to say what they mean to say and to express themselves clearly.

From the definition above, it can be seen clearly that games do not only provide supportive activities and practices that can motivate the students to interact and communicate, but games can also create opportunities for students to acquire the language in a meaningful way. In short, it can be said that games are able to help students use and practice the target language in a relaxed way. 
The function of game itself in teaching and learning process is can lower students' anxiety in using the target language, they will also highly motivating and entertaining so that the shy students will get more opportunities to express their opinion and feeling.

Further, Zdybiewska (as cited in Uberman,2002), she believes that games can be a good way in practicing the target language that being learned by the children, since they are able to provide a model of language on what the learners will use in the real life. Related to that statement, Kim (1995:35) presents six advantages of using games in the classroom, which are:

1. Games are motivating and challenging.

2. Games can be used as a welcome break from the usual routine of the language class.

3. Games help the students to make and sustain the effort of learning.

4. Games provide language practice in the various and integrated language skills.

5. Games encourage students to interact and communicate to each other.

6. Games create a meaningful context for language that is being learned by the students.

However, when do we have to use games? Actually, there are no fixed stages for using games in teaching and learning process. Traditionally, games have been used in the language class as warms-up at the beginning of class, fill-ins when there is extra time near the end of the class or as an occasional bit of spice stirred into the curriculum to add variety. However, more importantly, games can also constitute a more substantial part of the language courses. As for Mc Callum, (1980), "games can be used in any language teaching situation and with any skill area whether reading, writing, listening or speaking."

Holding the same viewpoint, Hadfield, (1987) also stated that "Games can be used at any stage of the lesson once the target language has been introduced and explained. They serve both as a memory aid and repetition drill and as a chance to use language freely, as a means to an end rather than an end in itself." But he also affirmed that "the most useful place for these games is at the free stage of the traditional progression from presentation through practice to free communication, to be used as a culmination of the lesson, as a chance for students to use language they've learnt 
freely." According to Wright, Betteridge \& Buckly (1983) put in " Games can be found to give practice in all the skills: reading, writing, listening or speaking in all stages of the teaching / learning sequence and for many types of communication."

In short, as Lee, (1979) observed, a game "should not be regarded as a marginal activity filling in odd moments when the teacher and class have nothing better to do." Games ought to be the heart of teaching foreign languages. Rixon (1981) suggested that games can be used at all stages of the lesson, provided that they are suitable and carefully chosen.

As we can see above, games are flexible activity. We can use it as warm up activity or do it in the end of the class, even we can use it as main activity. Besides that games also can be applied in all skills in English.

Therefore, games also can be applied in all level of the students since our students like playing game naturally.

Before discussing about the sample of games, we need to know how to organize games itself. In designing or organizing games, we need to pay attention to these factors, they are:

1. Timing: The teachers need to estimate the time of the game before running a game. Lewis and Bedson (1999) suggested that games should last from five to twenty minutes including preparation, presentation, game playing and post playing. It is important not to play a game for too long, students will lose their interest. It is best to stop a game at its peak.

2. Level of the games: Level of the games is another factor that the teachers should take into consideration when using language games in speaking lessons. Therefore, the teachers need to pay careful attention to the difficult level of the games. Part of the appeal of games lies in the challenge, but if the challenge is too great, some students may become discouraged. The teacher should also pay attention to the heterogeneity of the games. It means that the games should allow chance for both the bright and not-very- bright students. The chosen and adapted games should be relevant to the content of the lesson. It should be noted that even the most appropriate game will become meaningless if they are used repeatedly in different speaking lessons. Therefore, it is advisable that the teachers should exploit a variety of language games. 
3. Classroom language: When starting a game, the teacher should tell the students the rules of the game. It is one of the key factors that lead to the students' success in playing games. However, it is not simply enough to read out the rules of a new game or to hand out a written copy of the rules. Each game will need a proper introduction, which means an explanation-not just a reading-of the rules. When giving instructions, a few words in mother tongue are sometimes necessary as it would be the quickest way to make everything clear. It is a waste of time to throw students unprepared into an activity that they have not yet fully grasped: things will go wrong very quickly and the teachers will then have to spend more time trying to repair the situation. The teachers also need to demonstrate a short part of the game in which they actually make use of the language or the skill that the game is designed to practise, and then gradually get students joining in as according to many methodologists, games are best set up by demonstration rather than by lengthy explanation. Moreover, it is advisable that teachers make their demonstration as lively and appealing as possible so that students are motivated to join the game.

4. Classroom management: Language games would be very enjoyable and rewarding if they are handled in the right way. The way in which games are organized varies a great deal basing on specific purposes and particular game. Some games are played in pairs or in groups, some in teams and some with the whole class playing against the teacher. The formation of groups and pairs should initially be based on students' immediate neighbours to avoid noise and disruption. Thus, in pair work and group work, students choose the ones next to them, behind them or in front of them as partners. It is important that they can maintain face to face contact where sitting comfortably as it makes activities a lot easier. In short, the teacher must decide in advance how to organize the class so that, as Carrier (1985) stated: "the setting up of a game can be carried out as quickly and smoothly as possible." 
There are so many of examples of games which can be applied in teaching speaking skill in the class. However, not all of these kinds of game are suitable in improving the students' speaking abilities. In this particular game, we need to make sure that the main focus is to make the students speak or say something. One of the examples of game which can be used is "Chain Words". This game is designed to improve the students' ability in speaking by forming sentence from appropriate words. This game can be applied in intermediate, pre-advanced or even advanced students. For intermediate and pre-advanced students we can use controlled activity and for the advanced, we can use free activity.

This game actually requires the students to arrange words in order to form a good sentence by saying a word one by one. So, what the students need to do is just saying one word at a time orderly. However, the word must be coherent with the previous one. For example:

Students A: "She"

Students B: "She plays"

Students C: "She plays badminton"

Etc.....

The students who cannot add an appropriate word will be the loser and we can ask him/her to come forward to say the complete sentence done before. Besides that, we also can ask him/her to create another sentence which is similar (further explanation will be explained in the appendix).

This game will help the students in analysing the word (how to use the word) and being familiar with the function of the words in the sentence, whether they will be a subject, verb, object, adverb, or something else. Another advantage that we can get is the students will be aware and be more careful in choosing the appropriate word to be used in certain sentence unconsciously.

Another game which can be used in the classroom activity is "The truth Circle". This game is similar to what we usually do when we go camping. What we have to do is just ask the students to sit in circle and start spinning the bottle or something else, and the student who is pointed by the bottle will be the one who will answer anything asked by the others (further explanation will be explained in the appendix).

This game will attract the student attention, because sometime they will use this chance to ask everything they want 
about their friends. Another advantage we can get is our students usually are not really care about the use of grammar, they will just say something which is a good point in learning English, especially in speaking aspect.

From the discussion above, we can say that teaching English, especially teaching speaking skill, is not an easy job. There are a lot of aspects which need to be taken consideration. Due to this fact, we need tools or devices which can help us in delivering the material. One of them is by using game. Game is very useful activity to be applied in improving the students' ability in speaking skill. There are so many kinds of game which can be used, but it is essential to be remembered that the main goal is to make the students are able to say something or produce something in spoken form. However, before applying it, we should know what we should do and should not do in order to make the students can get the material optimally.

\section{CONCLUSION}

Teaching as well as providing appropriate speaking activities in classroom context is difficult. That is why it is essential for English teacher to use a certain technique which will help in teaching speaking skill to our students. As it was mentioned before, one of the best solutions is by using game. Game is a useful tool to be used. Naturally, game will attract the students' intention from the very beginning. Besides that, game can bring some enjoyment to the students and automatically it will make the students not only interested in playing it, but also can get the material or the idea being delivered effectively. However, it is also important to consider several things like; the classroom situation, the students' level, as well as the environment.

\section{REFERENCES}

Abidin, Zaenal. 2005. Teaching Speaking by Using Contextual Teaching and Through Learning Community at the Third Years Students at SMA Muhammadiyah Ponorogo 2005/2006. Published Thesis Unmuh Ponorogo.

Bygate, M. 1997. Speaking. Oxford: Oxford University Press.

Carrier, M. \& the others. 1985. Take 5 games and activities for the language leaning. UK: Thomas Nelson and Sons 
Hadfield, J. 1987. Elementary Communication Games. United Kingdom: Thomas Nelson and Sons

Lee, W.R. 1979. Language teaching games and contests. Oxford: Oxford University Press.

Lewis, G. and Bedson, G. 1999. Games for children. Oxford: Oxford University Press

Kim, Lee Su. 1995. Creative Games for The Language Class. Forum Vol 33 No.1 January-March 1995 Pg. 35.

Mc Callum, G.P. 1980. 101 Word Games. Oxford: Oxford University Press.

Mc Cabe, Allyse. 1992. Language Games to Play with Your Child: Enhacing Communication from Infancy through Late Childhood. New York:Insight Books Plenum Press.

Nguyễn Bàng \& Nguyễn Bá Ngọc. 2001. A course in TEFL theory and practice III: National University Publish

Richards, Jack C. 2008. Teaching Listening and Speaking (From Theory to Practice). Cambridge: Cambridge University Press.

Rixon, S. 1981. How to use games in language teaching. London: Macmillan Publishers.

Uberman, Agnieszka. 1998. The Use of Games for Vocabulary Presentation and Revision. Forum Vol 36 No.1 January-March 1998 pg 20.

Ur, Penny. 1996. A Course in Language Learning: Practice and Theory. Cambridge: Cambridge University Press.

Wright, A.; Betteridge, D. \& Buckly, M. 1983. Games for language learning. Cambridge: Cambridge University Press 